They note that Bianchini, during inquiries made in the Botanical Institute at Siena, found this species on the remains of exhumed corpses and that the patient described by Morax dealt with hides.

Coloured illustrations representing the growth as it appeared on various media, and the efflorescence, are not sent herewith as they would probably cost much to reproduce. Col. Acton has given me a copy of the original plates for the museum of the Government Ophthalmic Hospital, Madras, and I propose to send a duplicate to the Ophthalmological Department, London School of Tropical Medicine and Hygiene.

\title{
REFERENCES.
}

Morax, V.-Mycose de la cornée causée par le verticillium graphii. Ann d'Ocul., Vol. CXLIV, p. 323, 1910.

Vuillemin, P.-Sur un champignon parasite de l'homme, Glenospora graphii (Siebenmann). Comp. Rend. Acad. d. Sc., Vol. CLIV, p. 141, 1912.

Bianchini, G.-I miceti del cadavere umano. Atti d. R. Accad. d. Fisiocrit. in Siena, s.9, Vol. XV, p. 173, 1923-24.

Pollacci, G. and Nannizzi, A.-I miceti patogeni dell'uomo e degli animali. Siena, 1924.

\section{THE OPHTHALMOSCOPIC PICTURE OF NAEVUS (MELANOMA) CHOROIDEAE}

\author{
BY \\ KENNETH B. JOHNSTON \\ MONTREAL
}

THE object of this paper is to report three cases of naevi of the choroid, seen clinically, and to offer an explanation of their varying appearances.

I wish, here, to thank Dr. A. Fuchs for his interest as well as for his permission to publish the following three clinical cases which are from Professor Meller's Clinic in Vienna. Acknowledgment is also due to Prof. E. and Dr. A. Fuchs for their kindness in allowing me to study their pathological slides from nine cases of naevi.

The choroidal naevus is an important anomaly of pigmentation of the choroid. It has been extensively studied histologically and reported on by numerous authors, but few clinical reports can be found in the literature. Foster Moore ${ }^{1}$ describes four cases of melanoma of the choroid, one of which he examined histologically. He publishes clinical drawings and gives an extensive bibliography of previously reported cases. He says, "In size they varied from about one half the area of the optic disc to about four times its area. They were roughly circular, or oval in outline. The edges were everywhere quite definite without being quite hard and sharp. There was no fading off into the surrounding fundus, nor was there 


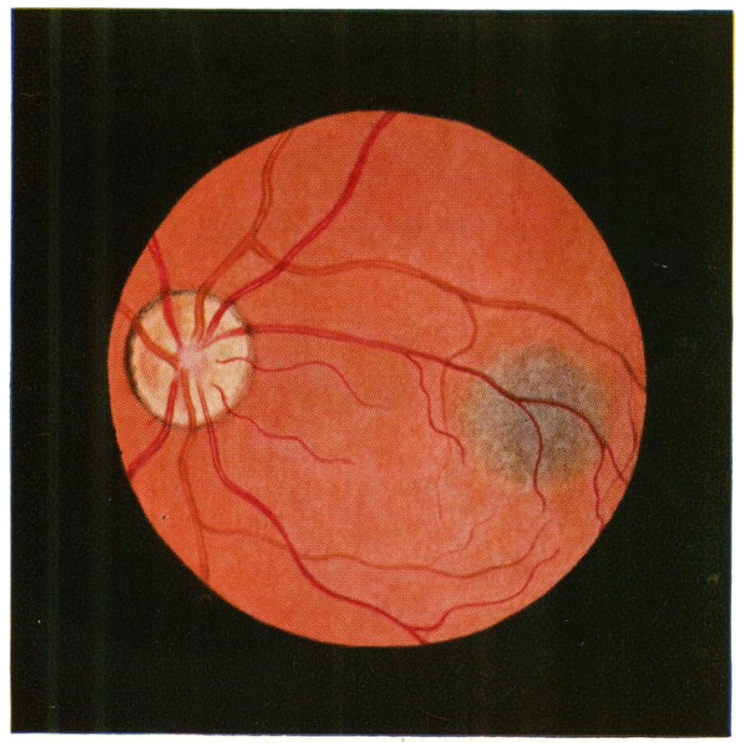

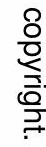

FIG. 1 
any fringe or evidence of pigmentary disturbance at the edge. They were of quite homogeneous appearance and the choroidal pattern though plainly seen around (in two cases) was not seen over the area of the growths. In colour they were exactly that of 'blue ointment' differing only in their density. All were single and close to the optic papilla the one farthest away being distant about two discs breadth."

In his histological description he states that the area is an intensely black circular spot entirely limited to the choroid, the overlying retinal pigment epithelium being quite uninvolved, and the choriocapillaris for the most part quite clear. In a later paper ${ }^{2}$ he publishes a second case again studied both clinically and histologically confirming these findings. $\mathrm{He}$ concludes that these growths are benign in character and probably congenital in origin.

In a discussion on melanomata ${ }^{3}$, Foster Moore reports that in an examination of one of his cases five years and two months later, the growth was quite unaltered in appearance. Another case three years later showed no change.

Usher $^{4}$ also at this discussion reports a similar case examined both clinically and histologically. This naevus appeared a dark grey, circular in outline, and edge not sharply defined. It was situated two discs diameters from the disc and was two-fifths of its size. It was crossed by the inferior temporal artery which was not appreciably raised. Microscopically this area showed a collection of pigmented cells that resembled normal choroidal chromatophores. These cells are brown, contain granular pigment but not in sufficient quantity completely to obscure the nuclei. The choriocapillaris is not invaded by these cells but the whole width of the choroid is thickened at the site of the melanoma.

E. Fuchs ${ }^{5}$ describes a case seen clinically, and publishes a series of excellent microphotographs of naevi from his collection including the section of the naevus from which the histological picture in this paper is reproduced.

A. Fuchs ${ }^{6}$ in his Atlas illustrates and describes a naevus.

Magitot ${ }^{7}$ reports a case in which the naevus had been missed ophthalmoscopically due to oedema of the nerve head but the histological sections show a typical naevus of the choroid which he reports in detail.

Some other observers describing this anomaly are Wolfrum, ${ }^{8}$ Dimmer, ${ }^{9}$ and Segalowitz. ${ }^{10}$

I wish to describe three cases of naevi because these show different clinical pictures according to the three possibilities of pigment distribution. These three well known types are the brownish-red fundus, the tessellated, and the albinotic fundus. These three types are produced by variations in the amount and colour of the pigment in the retinal pigment epithelium and the chromatophores of the choroid. 
Cases 1 and 3 are chance findings in patients who came for refraction, and have no sign of any disease present. Case 2 is a woman, aged 66 years, with senile cataract. Two weeks following cataract extraction, vision was $6 / 8$ and J.1.

Case 1 (Fig. 1). The naevus lies to the outer side of the macular region. It is a slightly elevated, round plaque, slate-grey in colour with an indistinctly defined margin. In size it is a little larger than the disc. The fundus is of a brownish-red colour; no details of the choroid are visible. The retinal vessels and disc are normal.

In this type of fundus the pigment epithelium contains a dense amount of dark pigment which completely obscures all the underlying choroidal details. For this reason one would expect a blurred outline of the naevus which, here, is actually the case. This fundus is the most common in appearance and the naevi, as a rule, are indistinctly outlined.

Case 2. In this case the naevus is situated above the macula, is slightly elevated and disc shaped. The size is approximately that of the optic disc, the colour is a slate-grey but the outline is quite definite. The fundus is tessellated, the choroidal vessels being seen everywhere as reddish bands except in the area of the naevus where they disappear. The disc and retinal vessels are normal. This naevus differs from Case 1 , in having a much sharper outline. The pigment epithelium in this eye is poorly pigmented. Thus not only are the choroidal details more visible but also the outline of the naevus. The appearance of such a naevus is much more rare than that of the first case.

Case 3. This naevus is found situated in the periphery of the fundus. The magnification is greater than in Fig. 1. Actually, it is slightly larger than the disc, of a slate-grey colour and with a sharp outline. Retinal vessels are seen running horizontally across the drawing as thin purplish-red lines, the upper one overlying the border of the naevus. The choroidal vessels, larger and of a brick-red colour, are seen sweeping from below upwards and across the naevus, like an open fan. The naevus is thus seen, crossed by both retinal and choroidal vessels, the latter in fact, appearing to groove it. Between the choroidal vessels, the intervascular spaces are unpigmented and filled by fine branching vessels, probably from the praecapillary layer. This is a case of naevus in an albinotic fundus where the outline of the naevus and choroidal vessels are clearly visible on account of the poor pigmentation of the pigment epithelium. It is especially interesting as it demonstrates clinically that the naevus lies in the outer layers of the choroid, since the choroidal vessels of the medium-sized layer (Sattler) are seen crossing it.

In the three cases there is seen no sign of any proliferation or change in the overlying pigment epithelium. 


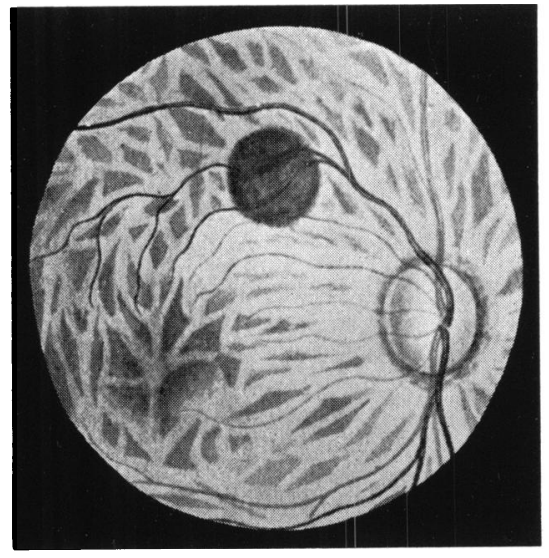

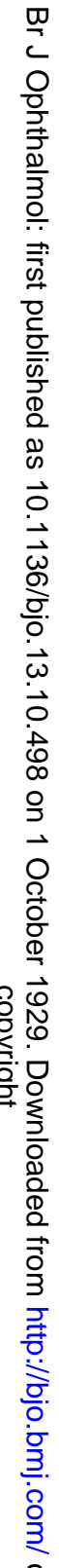

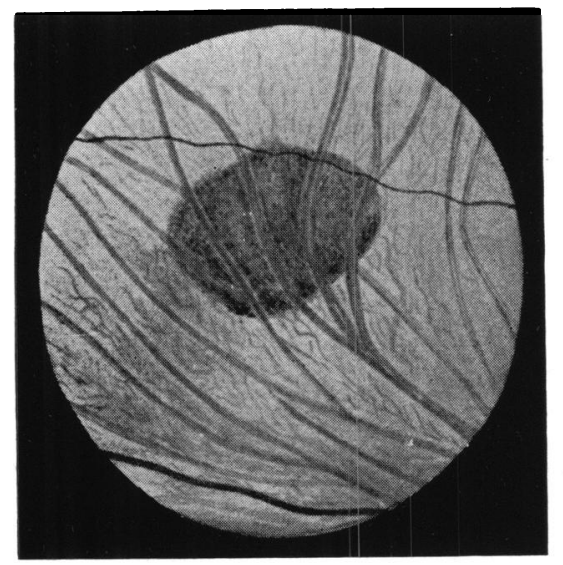

R.Y.

FIG. 2.

FIG. 3.

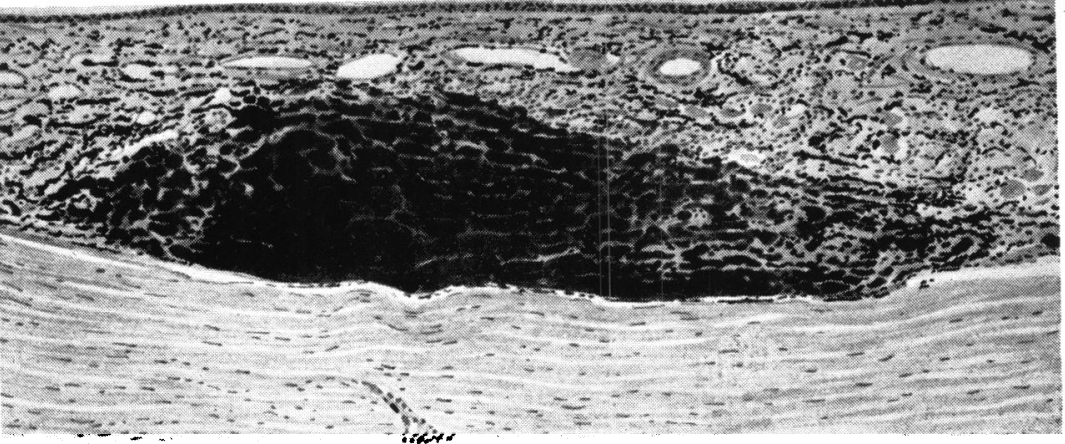

P.Epith.

윽

을.

N

Choroid

స్

₹

$\stackrel{0}{\bar{D}}$

Sclera

Fig. 4. 
In making a histological examination of naevi I do not wish to go into the detail of the histological structure but rather to enumerate the histological points which have a bearing on the clinical picture. Four of these cases were published by E. Fuchs in Arch. f. Ophthal., a fifth case appears in the Atlas of Histopathology of A. Fuchs, and four cases are new.

The histological drawing (Fig. 2) shows a naevus of the choroid lying in the external layers only. The outline of the naevus is more definite to the left than to the right. The pigment epithelium above is intact with a moderate amount of pigmentation. The choriocapillaris and several larger vessels of the middle layer are not invaded by the naevus cells. The cells themselves are densely pigmented although in the remainder of the choroid the chromatophores have only a very moderate pigmentation.

The accompanying chart shows the relation between the pigmentation in the pigment epithelium of the choroid and naevus. These nine cases were only histologically studied and had not been previously seen with the ophthalmoscope.

In all the cases but one the naevus lies in the neighbourhood of the disc. The width of the choroid in six was increased. I do not think, however, that the amount of the thickening would be enough to be measured by the ophthalmoscope. Foster Moore was doubtful of the measurement of $2 \mathrm{D}$. in one of his cases; Usher was unable to measure any swelling in his case.

In all the cases the naevi occupied the outer layers of the choroid leaving the choriocapillaris free. In three cases even Sattler's layer was partly free from naevi cells.

In all but one case I have noted the outline as definite. This is only a comparative term referable to the remainder of the choroidal pigmentation. The section of the naevi under the low power of the microscope has more of a rectangular than a pyramidal outline as might be expected from the feathered outline of the clinical picture. This blurring effect is due more probably to varying amounts of pigment in the overlying pigment epithelium. In five of the cases the pigment epithelium is noted as poor. One cannot be sure, however, if the amount of pigment that seems poor in a section is sufficient or not to hide the choroidal details in a clinical examination. The choroidal pigmentation was moderate in six cases, actually poor in two, and only dense in one case. On the other hand the pigment in the naevi cells was very dense in seven and moderate in two cases.

It is surprising that the clinical appearance is a slate-grey in spite of the dense black pigmentation of the naevus. Apparently only proliferation of the pigment epithelium can make a really black-looking pigmentation of the fundus, while the accumulations of the chromatophores give the effect of greyish discs. 


\section{Conclusions}

1. The colour of a true naevus clinically is always a uniform slate grey.

2. The outline varies from being feathery to sharp, depending on the amount of involvement of the inner layers of the choroid, and the amount and colour of the pigment in the pigment epithelium.

3. The elevation is rarely sufficient to be measured clinically, although the choroid is usually thickened.

4. The size and shape do not alter over long periods (five years) of observation. (Foster Moore).

5. The retinal pigment epithelium is not involved in the naevus.

Since sarcoma of the choroid tends usually to grow inwards, we may expect to see some sign of pigmentary disturbance of the pigment epithelium over the naevus as a very early sign of a beginning malignancy from such a source.

\begin{tabular}{|c|c|c|c|c|c|c|c|}
\hline No. & Location. & $\begin{array}{l}\text { Width of } \\
\text { choroid. }\end{array}$ & $\begin{array}{c}\text { Outline of } \\
\text { naevus. }\end{array}$ & $\begin{array}{c}\text { Vessels } \\
\text { NOT } \\
\text { involved } \\
\text { by naevus. }\end{array}$ & $\begin{array}{l}\text { Pigment } \\
\text { of pig. } \\
\text { epithel. }\end{array}$ & $\begin{array}{c}\text { Pigment } \\
\text { of } \\
\text { choroid. }\end{array}$ & $\begin{array}{c}\text { Pigment } \\
\text { of } \\
\text { naevus } \\
\text { cells. }\end{array}$ \\
\hline 1 & Near disc & $\begin{array}{c}\text { Not } \\
\text { thickened }\end{array}$ & Definite & $\begin{array}{l}\text { Chorio- } \\
\text { capillaris }\end{array}$ & $\begin{array}{l}\text { Chorio- } \\
\text { retinitic }\end{array}$ & Medium & Dense \\
\hline 2 & $\because \quad$. & Thickened & ." & $\begin{array}{l}\text { Choriocap. } \\
\text { and middle } \\
\text { layer }\end{array}$ & Medium & Poor & ", \\
\hline 3 & ". & .. & ." & Choriocap. & ". & Medium & ". \\
\hline 4 & $\begin{array}{l}5 \mathrm{~mm} \text {. } \\
\text { from disc }\end{array}$ & $\begin{array}{c}\text { Much } \\
\text { thickened }\end{array}$ & .. & ". & Poor & Dense & , \\
\hline 5 & Near disc & Thickened & .. & ". & ., & Medium & Medium \\
\hline 6 & $\begin{array}{c}\text { Near } \\
\text { Ora S. }\end{array}$ & $\begin{array}{c}\text { Not } \\
\text { thickened }\end{array}$ & Indistinct & ., & $\begin{array}{l}\text { Chorio- } \\
\text { retinitic } \\
\text { changes }\end{array}$ & ., & Dense \\
\hline 7 & Near disc & Thickened & Definite & $\begin{array}{l}\text { Choriocap. } \\
\text { compressed }\end{array}$ & Poor & $\because$ & ." \\
\hline 8 & $\begin{array}{l}5 \mathrm{~mm} \text {. } \\
\text { from disc }\end{array}$ & $\begin{array}{l}\text { Slightly } \\
\text { thickened }\end{array}$ & ., & $\begin{array}{l}\text { Choriocap. } \\
\text { and some } \\
\text { middle } \\
\text { vessels }\end{array}$ & Medium & .. & ". \\
\hline 9 & Near disc & $\begin{array}{l}\text { Not } \\
\text { thickened }\end{array}$ & ., & ". & Poor & Poor & Medium \\
\hline
\end{tabular}

Nos. 1-3 Reported by E. Fuchs.

. 4 , , Salzmann.

" 5 " $\quad$ " A. Fuchs (Atlas).

\#6 Atypical case.

, 7-9 Not previously reported. 


\title{
REFERENCES
}

1. Foster Moore.-Roy. Lond. Ophthal. Hosp. Rep., Vol. XIX, p. 411, 1914.

- Brit. Jl. of Ophthal., Vol. I, p. 26, 1917.

Trans. Ophthal. Soc. U K., Vol. XLVI, p. 120,1926.

Usher.-Trans. Ophthal. Soc. U.K., Vol. XLVI, p. 131, 1926.

Fuchs, E-Arch. f. Ophthal., Vol. XCIV, p. 43, 1917.

Fuchs, A.-Atlas of Histopathology, Vol. I, Plate 44, No. 3.

Magitot.-Ann. d'Ocul., p. 93, 1916.

Wolfrum.-Arch.f. Ophthal., Vol. LXXI, p. 278, 1909.

. Dimmer.-Der Augenspiegel.

10. Segalowitz.-Ophthal. Klinik, Vol. X, p. 225.

\section{EXOPHTHALMOS AND MIXED ASTIGMATISM CAUSED BY LARGE ETHMOID MUCOCELE}

BY

\author{
E. A. Seale, M.D. \\ Grahamstown, S. Africa.
}

Patient, a man aged 20 years, consulted me on February 15, 1928 , for a swelling about his left eye. He stated it began about four years previously and had gradually increased to its present size. Headaches were frequent and severe-the pain going through to back of head, and vision was affected. Some epiphora was present. There was a trifling redness over the swelling which occupied the inner orbital angle. On palpation it felt hard and firm; pressure gave a crackling which was both felt and heard. About its centre was a rather sharp, irregular-edged gap. Some oedema of the upper lid was noticeable. Proptosis was very marked. Forwards the eye extended $13 \mathrm{~mm}$., outwards $10 \mathrm{~mm}$., and downwards $5 \mathrm{~mm}$.

A history of severe influenza in the 1918 epidemic was given with several lighter subsequent attacks. On questioning as to injury he said that nine months previously he had a severe blow on the inner side of the left orbit through his head falling forward on to a tap, when recovering from gas in a dentist's chair. A bad " black eye" followed. About three months after this when blowing his nose a considerable quantity of thin yellowish fluid came away.

$\mathrm{R} . \mathrm{V} .=6 / 6$.

L.V. $=6 / 36$, with correction $=6 / 12$.

Muscles. Maddox rod, exophoria $2^{\circ}$. Hyperphoria $2^{\circ}$.

Fundus normal.

Maddox wing, exophoria $15^{\circ}$. Hyperphoria $0.5^{\circ}$.

Operation was advised, as condition was diagnosed as an ethmoidal mucocele.

A few days later the case was shown at a B.M.A. clinical meeting. The photograph here reproduced was taken March 1, 1928. 